\title{
A (des)organização coletiva em rede no Delicious: arquivos e sentidos em movimento*
}

Vivian Lemes Moreira**

Resumo: Esse trabalho tem como intento discutir as novas formas de organização dos recursos digitais inscritas pelo sujeito na rede eletrônica, a partir do processo coletivo da folksonomia, por meio das tags no website Delicious.

Palavras-chave: folksonomia; sujeito; heterogeneidade; rede eletrônica.

Apresentamos, nesse artigo, uma breve discussão no âmbito do discurso a respeito das novas formas de organização dos recursos digitais inscritas pelo sujeitonavegador na rede eletrônica, através do processo denominado como folksonomia. Este processo é caracterizado pela prática de categorização/indexação colaborativa das informações e arquivos na rede eletrônica utilizando tags, essas que funcionam como palavras-chave atribuídas pelo sujeito-navegador para indexar informação na web, atribuindo sentidos que ele deseja em conteúdos da malha digital, utilizando linguagem natural, ou seja, linguagem e vocabulário do "próprio" sujeito-navegador.

A partir dos pressupostos conceituais da Análise do Discurso de filiação francesa (AD), tal como postulado por Pêcheux (1989), investigamos o funcionamento discursivo da folksonomia, posto que, a partir desse processo é que são designadas as tags para organizar os arquivos e informações na web a partir de uma arquitetura de participação coletiva na rede. Inferimos que as tags são nomeações que compreendem os sentidos que estão disponíveis ao sujeito na posição que ocupa, já que o sujeito para a $\mathrm{AD}$ é uma posição no discurso sempre inserido em um dado contexto sócio-histórico e que ocupa um lugar de dizer, que não é rígido e implica um processo de captura instalado pela ideologia e pelo inconsciente. Assim, o sujeito é a todo tempo interpelado pela ideologia, definida como um mecanismo que torna os sentidos naturais e transparentes para ele na posição em que ocupa. A produção de evidências é o que determina o que "pode" e "deve" ser dito, a partir de uma posição numa dada conjuntura (PÊCHEUX, 1969), e isso ocorre a partir de uma formação discursiva (FD). Posto isso, colocamos que no processo da folksonomia o sujeito, ao inscrever sentidos á um determinado arquivo, é perpassado pela ideologia que provoca a naturalização de um conjunto de representações, saberes e dizeres possíveis para ele, fazendo parecer óbvio a leitura do arquivo de um modo e não de outro, que se utilize uma tag ao invés de outra.

Então, nesse processo de criação das tags também implica a FD à qual o sujeito está filiado, como também a memória discursiva a qual ele retornou para poder designar. O sujeito-navegador, ao inserir uma palavra-chave (tag) á um arquivo, link e

\footnotetext{
* Esse texto é um recorte do TCC "Movimentos do Sujeito na Rede Eletrônica: Uma Análise Discursiva sobre a Folksonomia" (2009).

** Mestranda na FFCLRP/USP. Bolsista CAPES. Pesquisadora do E-L@DIS - Laboratório Discursivo: sujeito, rede eletrônica e sentidos em movimento, da FFCLRP/USP. E-mail: viviannlk@gmail.com
}

fragmentum, N. 32. Laboratório Corpus: UFSM, Jan./ Mar. 2012 
ou informação na rede eletrônica por meio do processo da folksonomia, pode evocar diversos outros sentidos, pois a interpretação está ligada à posição que o sujeito ocupa e às redes de memória às quais ele está filiado. A memória discursiva é concebida como o saber fundante da linguagem, como condição do dizível; assim, não há discurso sem uma memória, que é sempre atualizada a cada dizer. Portanto, o sentido nunca é pronto ou acabado, e nunca se dá por definitivo, pois ele sempre está em relação com o já-dito. Por isso, faz-se necessária a compreensão de que as tags inscrevem-se a partir de uma memória discursiva dos sujeitos, já que é ela que permite também compreender a pluralidade dos gestos de leitura, de escrita e de interpretação. Para investigar como se dá o funcionamento discursivo das tags no ambiente da rede eletrônica, utilizamos recortes discursivos no sistema de favoritos on-line Delicious, que é tido como um sistema de bookmarking que permite o sujeito armazenar on-line seus sites favoritos e também compartilhá-los com outros internautas a partir de seu sistema colaborativo. A organização desses links favoritos é realizada através das tags, que são inscritas pelos próprios internautas, por meio do processo da folksonomia, como veremos agora.

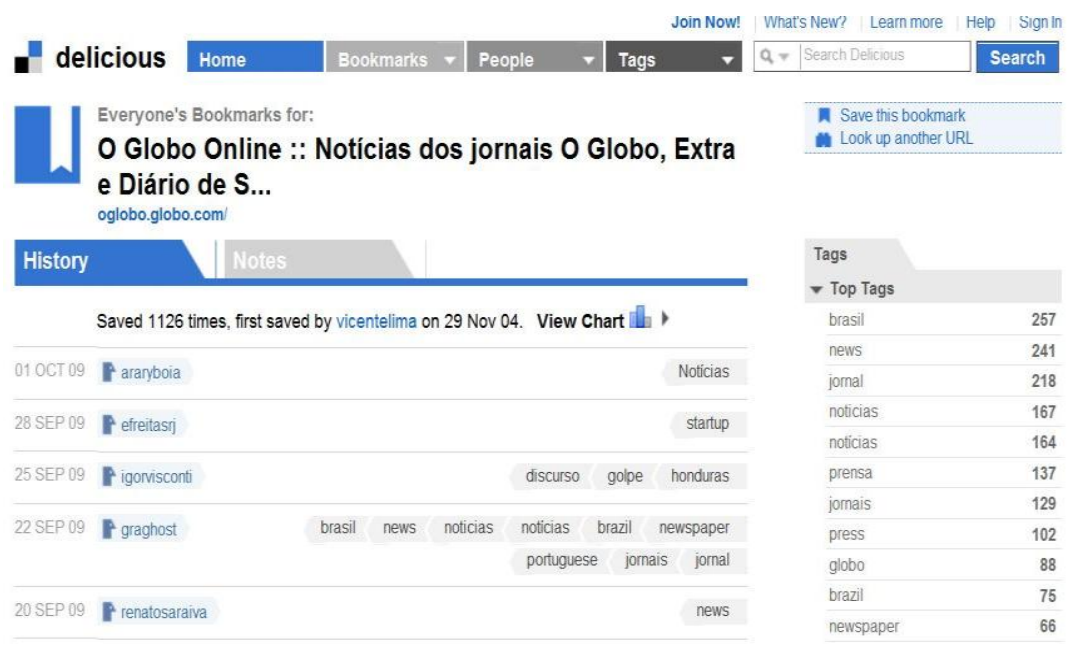

Figura 1 - O Globo.

Fonte: <http://delicious.com/url/934ea2fcaf85f96fa2c6e6f0df2bf708>.

A figura acima ilustra a forma como os sujeitos-navegadores indexaram o site "O Globo" por meio das tags; isso mostra o caráter heterogêneo da rede eletrônica, marcando uma dentre outras maneiras de compartilhamento, organização e ampliação das formas de publicação de dizeres e arquivos na rede. Tudo isso coloca em discurso a heterogeneidade dos dizeres por meio das pegadas, das marcas lingüísticas deixadas pelos sujeitos-navegadores, advindas de diferentes formações discursivas. Ao realizarmos um percurso por entre os nós da rede do Delicious, na tentativa de compreender a heterogeneidade de sentidos em fluxo, marcamos que os arquivos 
eletrônicos são indexados pelos sujeitos sem que exista um modelo prévio de leitura para a categorização/indexação, nem um manual fechado e ou uma lista de categorias e palavras-chave para tal processo. Observamos, então, que nas indexações da figura acima, o mesmo link recebe diferentes modos de dizer dos sujeitos-navegadores. Pontuamos que esse processo de atribuição de palavras que se dá através da posiçãosujeito está em ligação também com alguns atributos e às condições de produção da própria rede eletrônica, no qual podemos considerar a fluidez dos dizeres e arquivos instalados, a topologia não-linear e labiríntica em efeitos na organização do hipertexto, assim como os movimentos de dispersão, e a fragmentação e do/no Arquivo (ROMÃO; BENEDETTI, 2008).

A partir do pequeno recorte retirado do Delicious, observamos que esse sistema tem como intuito o compartilhamento de arquivos, links, e textos de diferentes materialidades, enfim, de campos de documentos sobre uma certa questão, ao modo que Pêcheux (1997) definiu o arquivo. Esse lugar discursivo configura-se a partir de uma con-fusão de vozes, que permite que ao sujeito realizar pesquisas, dizer aos outros por meio dos seus próprios favoritos, instalar(-se) na rede eletrônica um ambiente heterogêneo em que várias vozes entrecruzam-se (MOREIRA, ROMÃO, 2008). Ao problematizarmos o modo como as informações são organizadas e disponibilizadas na rede pelo processo da folksonomia, buscamos indagar como ele (se) constrói deslocamentos de sentidos, significa o(s) arquivo(s) e produz efeitos de ordenamento discursivo marcado pelos movimentos dos sujeitos-navegadores.

\section{Referências}

MOREIRA, V. L. ROMÃO, L. M. S. É Del.icio.us estar na rede: ideologia e discurso do sujeito navegador. E-compós, v. 11, n. 3, Brasília, set./dez.2008.

PÊCHEUX, M. Ler o arquivo hoje. In: ORLANDI, E. (org.). Gestos de leitura. Campinas, SP: Editora da Unicamp, 1997.

. Análise automática do discurso (AAD-69). In: GADET, F.; HAK, T. (orgs.). Por uma análise automática do discurso. Uma introdução à obra de Michel Pêcheux. Campinas, SP: Editora da Unicamp, 1990.

ROMÃO, L. M. S.; BENEDETTI, C. A navegação do sujeito no discurso jornalístico impresso e eletrônico. Verso e reverso, v. 22, 2008. 